\title{
Scanning electron microscopic studies of antennal sensilla of adult worker Apis florea F (Hymenoptera: Apidae)
}

\author{
M Gupta \\ Haryana Agricultural University, Department of Zoology, \\ Laboratory of Animal Behaviour and Simulated Ecology. Hisar-125 004, Haryana, India
}

(Received 10 January 1989; accepted 25 October 1991)

\begin{abstract}
Summary - The micromorphology of the antennae of the honey bee Apis florea $\mathrm{F}$ was studied. The number and distribution of the various types of sensilla were examined. Sensilla observed were sensilla placodea, basiconica, trichodea, ampullacea, coeloconica and campaniformia. Sensilla trichodea were found most frequently and were present on all the antennal segments. Sensilla placodea and sensilla basiconica were present on 8 distal segments. Sensilla ampuliacea and sensilla coeloconica were present on 5 distal segments while sensilla campaniformia were confined to 7 distal segments. The highest density of sensillae was found on the distal antennel segment. The distribution of different types of sensilla on the antenna resembled that described for other Apis species.
\end{abstract}

Apis florea / antenna / sensilla / morphology / SEM

\section{INTRODUCTION}

The honey bee, Apis florea $\mathrm{F}$ acts as a pollinating agent of some crops in the hot climates of the Indian sub-continent (Rahman, 1940; Rauala, 1972). This paper presents an initial study of the olfactory system of this insect.

The antennae are the main sites of olfactory receptors in most insects (Wigglesworth, 1965). Scanning electron microscopic (SEM) studies of worker honey bees, Apis mellifera, have been carried out earlier (Slifer and Sekhon, 1960; Slifer, 1970; Dietz and Humphreys, 1971) and also on many other Hymenopterans
(Norton and Vinson, 1974; Argen, 1977, 1978).

This study describes the types and distribution of sensilla on the antennae of Apis florea $\mathrm{F}$ workers as revealed by SEM (the first being undertaken by Gupta, 1986) and compares these results with other studies in the literature. The major objective of this work was to examine the external aspects of various sensilla and their distribution pattern. This information will be useful at a later stage in conducting physiological studies associated with behaviour to determine whether morphologically similar structures have been homologized within different taxa. 


\section{MATERIALS AND METHODS}

Specimens were collected from fields located near Haryana Agricultural University during March 1981.

The antennae of $A$ florea worker bees were ctipped, air-dried over silica gel and mounted on aluminium stubs with adhesive tape and silver glue. The preparations were coated under vacuum with a $35-\mathrm{mm}$ layer of pure gold in a sputter coating unit. The antennae were viewed and photographed using a Phillips PSEM 501 B at an accelerating voltage of $7.2 \mathrm{kV}$.

Counts of sensilla were made directly from the SEM video monitor. The side of the antenna against the head was defined as the upper and the side away from the head as the under side. The segments starting from the proximal to distal end of the antenna were designated as $\mathrm{Se}_{1}$, $\mathrm{Se}_{2}$ and so on.

\section{RESULTS}

The antenna of worker bees of $A$ florea had 10 segments. Its length varied from $3.0-3.5 \mathrm{~mm}$. The last segment had a blunt roundish end. The distribution of different types of sensilla along the antenna is illustrated in figs 1, 2 and table I.

Most of the sensory structures found on the antenna of worker bees are situated on the 8 distal segments. The remaining 2 segments of the flagellum are exclusively covered with sensilla placodea. Sensilla placodea and setae occupy distinct zones on the segments with very little overlapping. Scape and pedicel only have hairs and are completely devoid of setae and sensilla (fig 3 ). The surface is rough in the setae-rich zone and smooth in the sensilla placodea-rich zone.

Setae are found on all the segments of the flagellum. The first 2 segments are dominated by setae 2-33 $\mu \mathrm{m}$ long (mean $15 \mu \mathrm{m}$ ) 0.68-2.3 $\mu \mathrm{m}$ width (mean $1.3 \mu \mathrm{m}$ ). Proximally in $\mathrm{Se}_{1}$, they appear needle-like (fig 4) and incline close to the surface but

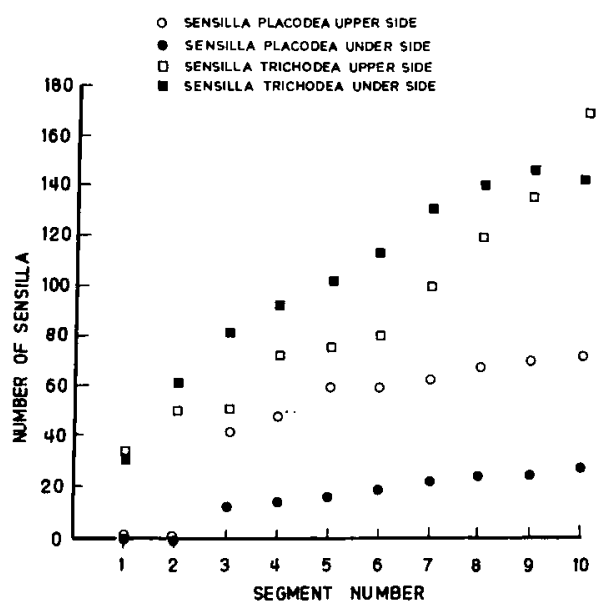

Fig 1. Mean number and distribution of sensilla placodea and sensilla trichodea on the antennae of Apis florea workers.

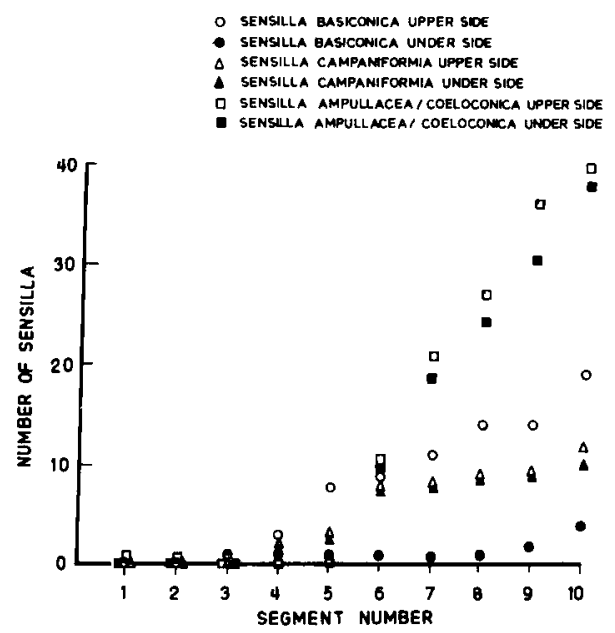

Fig 2. Mean number and distribution of sensilla basiconica, sensilla campaniformia and sensilla ampullacea/coeloconica on the antennae of Apis florea worker honey bees. 
Table I. Counts of sensilla on the antennae of Apis florea.

\begin{tabular}{lcc}
\hline Sensillum type & $\begin{array}{c}\text { No * of sensilla } \\
\text { Upper side (dorsal side) } \\
\text { Mean }\end{array}$ & $\begin{array}{c}\text { Under side (ventral side) } \\
\text { Mean }\end{array}$ \\
\hline Sensilla placodea & $482 \pm 14.4$ & $163 \pm 12.4$ \\
& $(0-72)$ & $(0-28)$ \\
Sensilla trichodea & $887 \pm 34.6$ & $1066 \pm 40.4$ \\
Sensilla basiconica & $(35-166)$ & $(34-146)$ \\
& $80 \pm 14.1$ & $12 \pm 0.3$ \\
Sensilla campaniformia & $(0-19)$ & $(0-4)$ \\
& $50 \pm 4.4$ & $(0-10)$ \\
Sensilla coeloconica/ & $(0-12)$ & $130 \pm 16.6$ \\
ampullacea & $139 \pm 18.1$ & $(0-38)$ \\
Total & $(0-40)$ & $1428 \pm 73.8$ \\
& $1638 \pm 55.6$ & $(34-326)$ \\
\hline
\end{tabular}

* Mean $\pm \mathrm{SD}$, based on all the segments of 15 antennae, values in parentheses represent ranges of sensilla per segment. Note: All means rounded to the nearest whole number.

gradually become knife- or sabre-like and erect on reaching the sensilla placodea field. The setae are larger on the inner side of the antenna (fig 5). The outer side of $\mathrm{Se}_{10}$ has smooth and curved setae. A few bifid and trifid setae are present on the flagellum. Some setae are patterned (fig 6). More sensilla trichodea were found than any other type. Other sensilla occurred with decreasing frequency: sensilla placodea > sensilla coeloconica/sensilla ampullacea > sensilla basiconica > sensilla campaniformia.

Sensilla placodea were distributed from the proximal end of $\mathrm{Se}_{3}$ to the last segment, $\mathrm{Se}_{10}$. There were 3 times as many on the upper side (dorsal side) as on the under side (ventral side). They occurred as oval pore plates with a thick, slightly raised rim and indistinct furrows all around (fig 7). Sensilla trichodea were most abundant.
These were found on all the segments of the antenna. These were 0.83 times as many on the upper side as on the under side. This type of sensillum was ultrastructurally segregated into types $A, B$ and $C D$ (figs 7-9). Sensilla trichodea $A$ had a blunt tip (fig 9, inset). Sensilla trichodea B occurred in sharply bent forms. Sensilla trichodea CD type were curved. Sensilla basiconica were less visible at the apex. They were lodged in a distinct socket and were thick with blunt depressed tips, probably indicating a pore (fig 10).

Sensilla campaniformia occurred on the 7 distal segments of the antenna. The wall around the bulb had a button-like knob (fig 11). Sensilla ampullacea and sensilla coeloconica occurred on the 5 distal segments on the antenna. Sensilla ampulacea had smaller pores whereas sensilla coeloconica showed wide pores (figs 11, 12). 

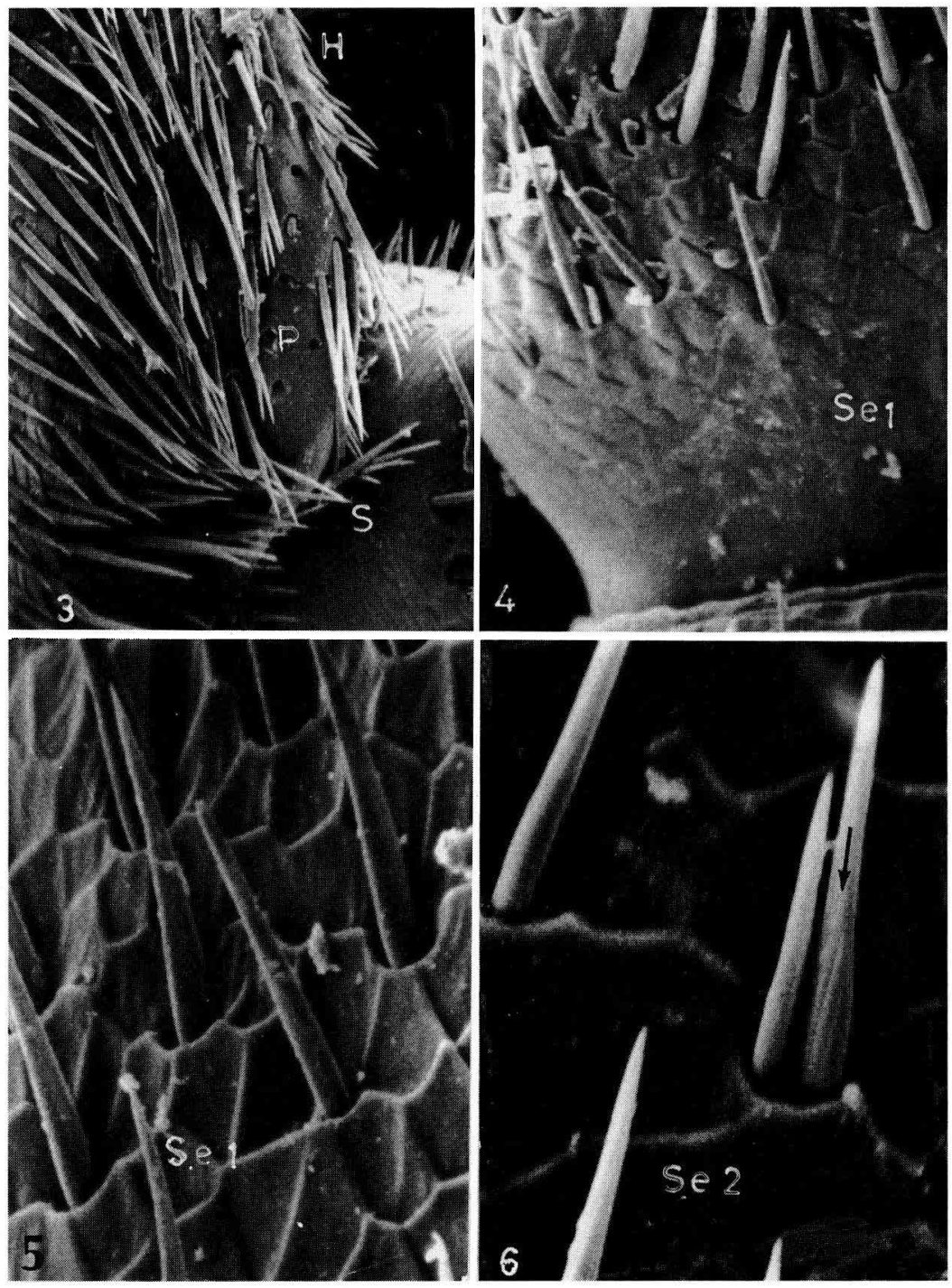

Figs 3-6. 3. SEM image showing pedicel $(P)$ of Apis florea possessing exclusively needle-like hair $(\mathrm{H}) . \mathrm{S}=$ Scape $\times 2625.4$. SEM image showing proximal portion of first segment $\left(\mathrm{Se}_{1}\right)$ of the flagellum of Apis florea. Note sabre- and needle-like setae $\times 1312$. 5. SEM image showing distal portion of first segment $\left(\mathrm{Se}_{1}\right)$ of the flagellum of Apis florea. Note sharp-tipped setae $\times 2$ 625. 6. SEM image showing a portion of second segment $\left(\mathrm{Se}_{2}\right)$ of the flagellum of Apis florea. Note the adjoining position of setae; one of the seta is patterned (arrow) $\times 5250$. 

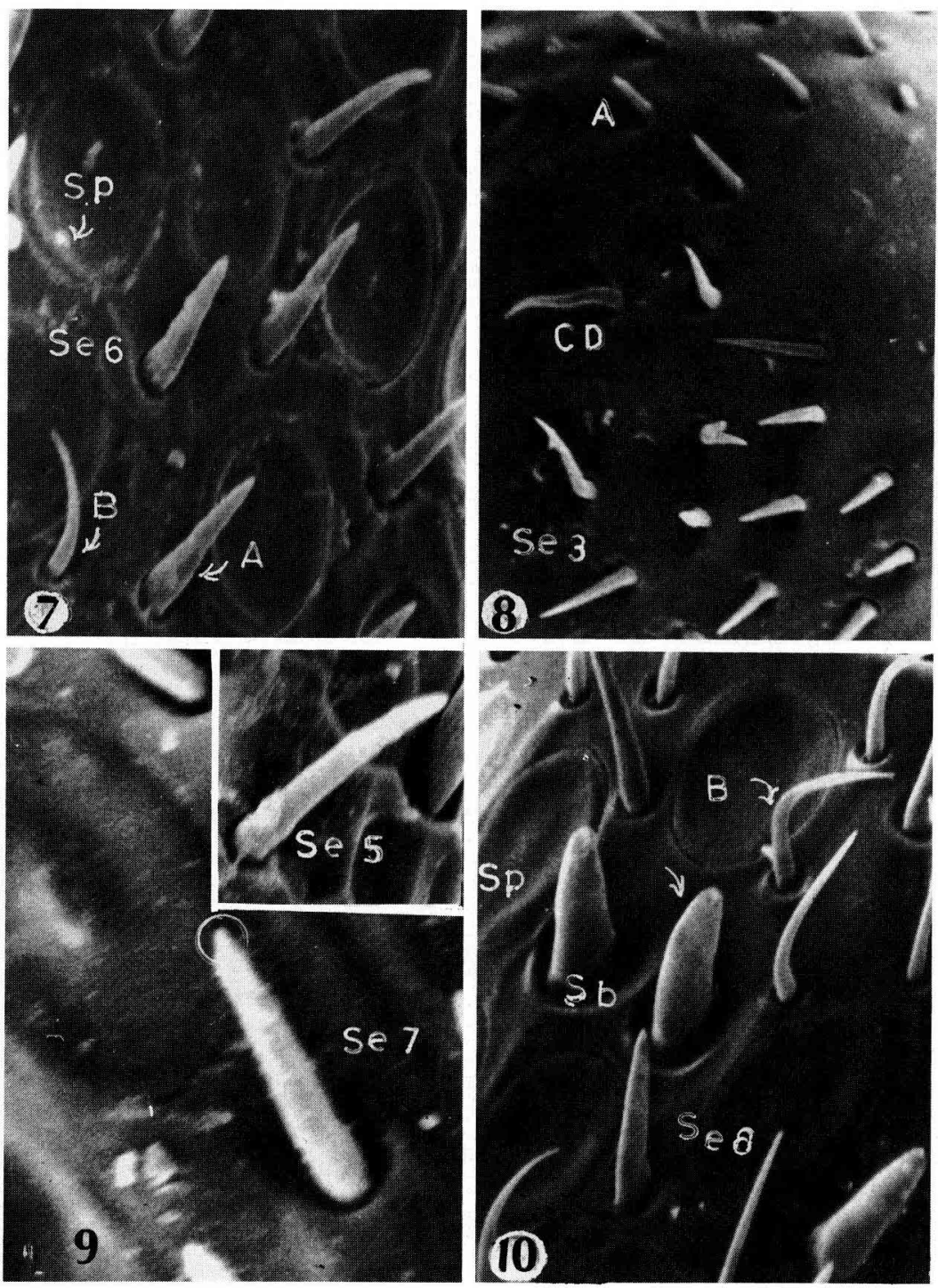

Figs 7-10. 7. SEM image of a portion of $\mathrm{Se}_{6}$ of the antenna of Apis florea. Note sensilla placodea (SP) with slightly raised centres. Middle plate of SP is depressed which causes the thin membrane to hang down on the ridge, seen as an edge (arrow) $\times 1312$. 8. SEM image showing a portion of $\mathrm{Se}_{3}$ of the antenna of Apis florea. Note sensilla trichodea types $A$ and $C D \times 875$. 9. SEM image showing a portion of $\mathrm{Se}_{7}$ of the antenna of Apis florea. Note sensilla trichodea with papilla at the tip $\times 3500$. Inset: sensillum trichodeum type $A$ with blunt tip of $\mathrm{Se}_{5} \times 2$ 625. 10. SEM image showing a portion of Se8 of the antenna of Apis florea. Note the presence of sensilla basiconica (sb), sensilla trichodea types A and B and sensilla placodea (sp). Indentation on tip is a pore (arrow) $\times 2625$. 

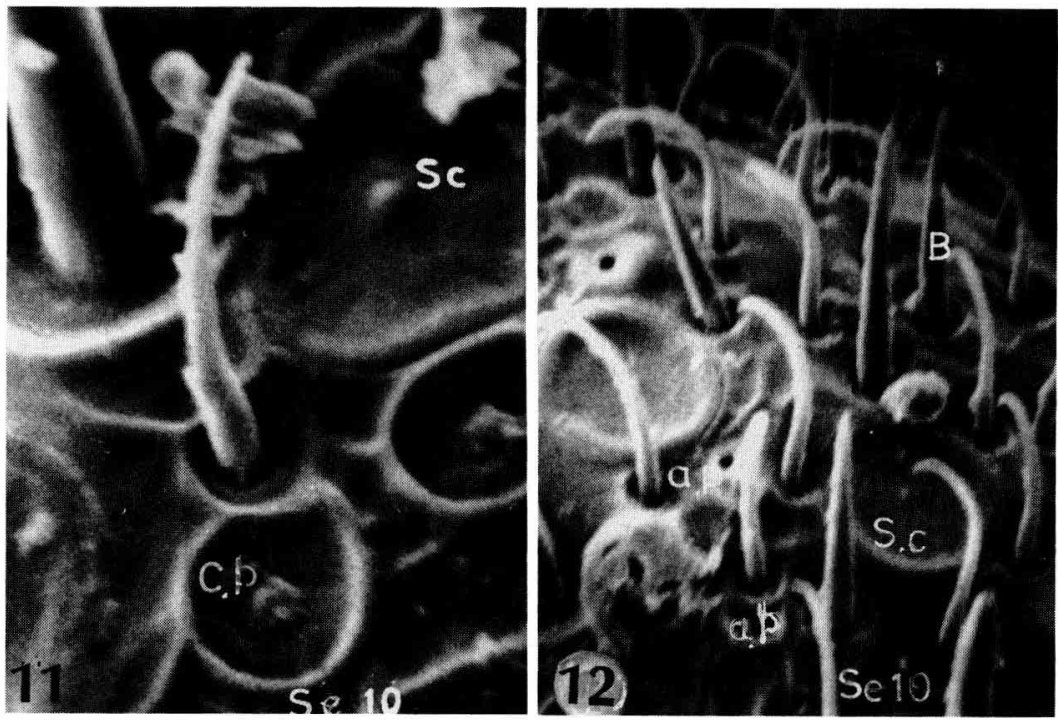

Figs 11-12. 11. SEM image showing a portion of $\mathrm{Se}_{10}$ of the antenna of Apis florea. $\mathrm{Cp}=$ sensilla coeloconica, $\mathrm{Sc}=$ sensilla campaniformia $\times 2625$. 12. SEM image from the tip of $\mathrm{Se}_{10}$ of the antenna of Apis florea. $\mathrm{Sc}=$ sensilla campaniformia; ap = sensilla ampullacea $\times 1312$.

\section{DISCUSSION}

The location of different types of sensilla on antenna of $A$ florea is similar to those of A mellifera. But the population of the types of olfactory sensilla was comparatively much less on the antenna of $A$ florea (Bhardwaj, 1974; Gupta, 1982) than on $A$ mellifera (Dietz et al, 1974). The distribution of various types of sensillae along the antenna is similar to that found in other Apis species.

Sensilla trichodea type A are the most common structures on the antenna. The morphology of this sensillum indicates an olfactory function (Slifer and Sekhon, 1961). The olfactory function of sensilla trichodea over the year was also hypothe- sized by various workers (Vogel, 1921; Frisch, 1967; Schneider, 1968; Dietz and Humphreys, 1971). However, Lacher (1964) reported that sensilla trichodea type A did not respond to any chemical stimuli but sensilla trichodea type $\mathrm{B}$ responded to mechanical stimuli in $A$ mellifera. In Apis, Martin and Lindauer (1966) found some of these sensilla on the distal antennal segment of $A$ mellifera and suggested that they may be used to decipher wax smoothness. This type of arrangement of sensilla was neither observed in this study nor is it frequently encountered in other bees. Esslen and Kaissling (1976) suggested a gustatory function of sensilla trichodea type $\mathrm{CD}$. It has also been reported that the sensilla trichodea are the sex pheromone receptors on the male spruce budworm Cho- 
ristoneura fumigarana (Albert et al, 1974) and the male red banded leaf roller Aroyrotaenia velutinana (O'Connell, 1972, 1975).

The sensilla placodea have been shown to be odour receptors in A mellifera (Lacher and Schneider, 1963; Kaissling and Renner, 1968). Sensillum basiconicum has an apical pore at its tip. Although there is no evidence from the present morphological investigation to indicate the presence of a closing - opening mechanism of the apical pores, such a process is known for the terminal pores of gustatory sensilla in Schistocerca gregaria (Blaney and Chapman, 1969), Locusta migratoria (Blaney et al, 1971) and the blowflies Phormia regina and Calliphora vicinia (Sturchow et al, 1973). Slifer et al (1959) and Schneider et al (1964) thought that sensilla basiconica participated in chemoreception in grasshoppers and moths, and the pores present in their walls are much suited for the perception of olfactant molecules.

In sensilla ampullacea and sensilla coeloconica the surface around the pore is smooth in $A$ florea (figs 11,12 ) in contrast to A mellifera in which it was patterned (Argen, 1975). These have been shown to respond to carbon dioxide in $A$ mellifera (Lacher, 1964), temperature in Aedes aegypti (Davis and Sokolove, 1975) and Periplanta americana (Altner et al, 1977) and humidity in $P$ americana (Yokohari and Taneda, 1976; Altner et al, 1977; Yokohari, 1978). Sensilla campaniformia are probably mechanoreceptors (Pringle, 1938; Esslen and Kaissling, 1976; Yokohari and Taneda, 1976; Yokohari, (1978) reported the presence of campaniform sensilla on cockroach legs which are mechanoreceptors and responded to the stresses of the cuticle. Campaniform sensilla are found to occur in association with ampullaceous and coeloconic sense organs and hence these may be considered sensitive to temperature, carbon dioxide and humidity or a combination of these factors. This speculation is based on the electrophysiological findings of Lacher (1964) for A mellifera.

All Apis species studied so far possess similar types of sensilla on their antennae. It is the distribution of these sensilla along the antenna that differs among species. The similarities in distribution among the Apis species are pronounced. Less similarity occurs in distribution if one compares A florea with less closely related Hymenoptera.

\section{ACKNOWLEDGMENTS}

The valuable assistance of the late RP Kapil and the technical aid of $V$ Sethi and SCP Sharma are gratefully acknowledged. The study was supported by Haryana Agricultural University, Hisar, India. I am grateful to RC Sihag for helpful discussion.

\section{Résumé - Étude en microscopie élec- tronique à balayage des sensilles de l'antenne chez l'ouvrière adulte d'Apis florea (Hymenoptera, Apidae). Les ré-} cepteurs sensoriels du flagelle des ouvrières d'Apis florea ont été étudiés en microscopie optique et en microscopie électronique à balayage (MEB). L'antenne comprend le scape, le pédicelle et le flagelle constitué de 10 segments. Le scape et le pédicelle n'ont que des poils en forme de plumes mais aucune structure semblable aux soies ou aux sensilles du flagelle. Les soies prédominent sur les 2 premiers segments du flagelle. On n'observe pas de séparation nette entre les sensilles et les zones de soies. La distribution et le nombre des divers types de sensilles (trichodea, placodea, basiconica, ampullacea, coelonica et campaniformia) ont été déterminés. Les sensilla trichodea sont les plus nombreuses et présentes sur tous les segments du flagelle. Les sensilla placodea et 
basiconica sont présentes sur les 8 segments terminaux. Les sensilla ampullaceal coelonica sont présentes sur les $5 \mathrm{seg}$ ments terminaux et les sensilla campaniformia sur les 7 derniers. Certaines sensilla basiconia présentent une dépression montrant un pore à l'apex. Trois types de sensilla trichodea sont présents; les sensilla trichodea A sont fines et droites, les B sont courbées. Les types $C$ ou $D$ sont incurvés mais difficiles à distinguer l'un de l'autre. Les sensilla ampullacea/coelonica et les campaniformia se présentent par groupes dans la même région. Les sensilla ampullacea sont plus petites que les coelonica, elles-mêmes plus petites que les campaniformia. Ces dernières sont les moins nombreuses.

Apis florea / antenne / sensille / morphologie / MEB

\section{Zusammenfassung - Rasterelektro- nenmikroskopisches Studium von den Fühlerssensillen der Arbeitsbiene Apis florea (Hym, Apidae). Die sensorischen Rezeptoren am Flagellum der Arbeiterin- nen von Apis florea wurden mittels Licht - und REM-Mikroskopie untersucht. Die An- tenne besteht aus Schaft, Pedicel (Sockel) und 10-gliedriger Geißel (Flagellum).} Schaft und Sockel tragen nur gefiederte Haare und keine Strukturen ähnlich den Borsten und Sensillen der Geißel. Die ersten beiden Segmente der Geißel sind vor allem mit Borsten besetzt. Zwischen den Arealen der Sensillen und der Borsten ist keine klare Abgrenzung zu erkennen. Es wurden Verteilung und Populationen von Sensilla trichodea, Sensilla placodea, Sensilla basiconica, Sensilla ampulacea, Sensilla coeloconica und Sensilla campaniformia bestimmt. Die Sensilla trichodea waren am häufigsten und wurden auf allen Geißelsegmenten gefunden. Sensilla placodea und $S$ basiconica waren an den acht distalen Segmenten vorhanden. Sensilla ampulacea und $S$ coeloconica waren auf fünf, $S$ campaniformia auf sieben distale Segmente beschränkt. Die größte Sensillendichte wurde auf dem letzten Geißelsegment gefunden. Einige $S$ basiconica waren in die Oberfläche eingesunken, so daß sie den Eindruck einer Pore erweckten. Es gab drei Typen von $S$ trichodea: Sensilla trichodea $A$ waren schlank und gerade; $S$ trichodea B waren gebogen; $S$ trichodea vom Typ $C$ oder D waren kurvenförmig, aber in der gegenwärtigen Studie sehr schwer voneinander zu unterscheiden. $S$ ampullacea, $S$ coeloconica und $S$ campaniformis traten in Gruppen in demselben Feld auf. $S$ ampullacea waren kleiner als $S$ coeloconica, die ihrerseits kleiner waren als $S$ campaniformia. In geringster Häufigkeit traten $S$ campaniformia auf.

\section{Apis florea / Antenne / Sensille / Mor- phologie / REM}

\section{REFERENCES}

Albert PJ, Seabrook WD, Paim U (1974) Isolation of a sex pheromone receptor in males of the eastern spruce budworm Choristoneura fumiferana (Clem) (Lepidoptera: Tortricidae). $J$ Comp Physiol 91, 79-89

Altner $H$, Sass H, Altner I (1977) Relationship between structure and function of antennal chemo-hygro-, and thermoreceptive sensilla in Periplaneta americana. Cell Tissue Res 176, 389-405

Argent $L$ (1975) Comparison between air drying and critical point drying for SEM studies of the antennae of Apis mellifera $L$ (Hymenoptera: Apidae). Zoon 3, 213-238

Argen L (1977) Flagellar sensilla of some Colletidae (Hymenoptera: Apoidea). Int I Insect Morphol Embryol 6, 137-146

Argent L (1978) Flagellar sensilla of two species of Andrena (Hymenoptera: Andrendidae). Int $J$ Insect Morphol Embryol 7, 73-79 
Bhardwaj SC (1974) Evaluation of some chemicals as repellents to Apis florea F. Ph D thesis, Haryana Agric Univ, Hisar, India, 125 pp

Blaney WF, Chapman RF (1969) The fine structure of the terminal sensilla on the maxillary palps of Schistocerca gregaria (Forskol) (Orthoptera: Acaridae). Z Zellforsch 99, 74-97

Blaney WF, Chapman RF, Cook AG (1971) The structure on the maxillary palps of Locusta migratoria $(L)$ and changes associated with moulting. $Z$ Zellforsch Anat 121, 43-68

Davis EE, Sokolove PG (1975) Temperature responses of antennal receptors of the mosquito, Aedes aegypti. J Comp Physiol 6, 223-236

Dietz A, Humphreys WJ (1971) Scanning electron microscopic studies of antennal receptors of the worker honey bee, including sensilla campaniformia. Ann Entomol Soc Am $64,919-925$

Dietz A, Anderson LM, Sanford MT (1974) Fractographic studies of the honey bee sensilla coeloconica, sensilla ampullacea and sensilla campaniformia by SEM. In: 32nd Ann Proc Electron Microsc Soc Am (Arsceneaux CJ, eds) St Louis, MO, Ithaca, USA

Esslen J, Kaissling KE (1976) Zahl und Verteilung antennalar Sensillen bei der Honigbiene (Apis mellifera L). Zoomorphologie 83, 227251

Frisch KG (1967) The Dance Language and Orientation of Bees. Harvard Univ Press, Cambridge, MA, $566 \mathrm{p}$

Gupta M (1982) Olfactory physiology of Apis florea $\mathrm{F}$ with reference of repellents. $\mathrm{Ph} D$ Thesis. Haryana Agric Univ, Hisar, India, $169 \mathrm{p}$

Gupta M (1986) A quantitative study of flagellar sensillae of Apis florea $F$ (Hymenoptera: Apidae). Proc Ind Acad Sci (Anim Sci) 95, 595603

Kaissling KE, Renner M (1968) Antennale Rezeptoren für Queen Substance and Sterzelduft bei der Honigbiene. Z Vgl Physiol 59, 357-361

Lacher V (1964) Elektrophysiologische Untersuchungen an einzelnen Rezeptoren für $\mathrm{Ge}$ ruch, Kohlendioxid, Luftfeuchtigkeit and Temperatur auf den Antennen der Arbeitsbiene und der Drohne (Apis mellifera L). Z Vgl Physiol 48, 587-625

Lacher V, Schneider D (1963) Elektrophysiologischer Nachweis der Riechfunktion von paaren Platten (Sensilla Placodea) auf den Antennen der Drohne und der Arbeitsbiene (Apis mellifera L). Z Vg/ Physiol 47, 274-278

Martin H, Lindauer M. (1966) Sinnesphysiologische Leistungen beim Wabenbau der Honigbiene. Z Vgl Physiol 53, 372-404

Norton WN, Vinson SB (1974) A comparative ultrastructural and behavioural study of the antennal sensory sensilla of the parasitoid Cardiochiles nigriceps (Hymenoptera: Bracoidae). J Morphol 142, 329-350

O'Connell RJ (1972) Responses of olfactory receptors to the sex attractant, its synergist and inhibitor in the red banded leaf roller. In: Olfaction and Taste IV (Schnedier D, ed) Wissenschaftliche Berlagagesellschaft $\mathrm{GmbH}$, Stuttgart, 180-186

O'Connell RJ (1975) Olfactory receptor responses to sex phermonome components in the red banded leaf roller moth. J Gen Physiol $65,179-225$

Pringle JWS (1938) Proprioception in insects. II. The action of campaniform sensilla on the leg. J Exp Biol 15, 114-131

Rahman KA (1940) Insect pollinators of Toria (Brassica napus Linn var dichotoma Prain) at Lyallpur. Ind J Agric Sci 10, 422-447

Rauala TS (1972) Pollination studies in cauliflower (Brassica oleracea var botrytis). Punjab Agric Univ J Res 9, 581-585

Schneider D (1968) Basic problems of olfactory research. In: Theories of Odour Measurement. (Tanyola CNT, ed) 201-211

Schneider D, Lacher V, Kaissling KE (1964) Die Reaktionsweise und das Reaktionspektrum von Riechzellen Beinntheraea pernyi (Lepidoptera: Saturniidae). Z Vgl Physiol 48, 632-662

Slifer EH (1970) The structure of arthropod chemoreceptors. Annu Rev Entomol 15, 121142

Slifer EL, Sekhon SS (1961) The fine structure of the plate organs in the antennal flagellum of the honey bee Apis mellifera L. J Morphol 109, 351-381

Slifer EH, Prestage JJ, Beams HW (1959) The chemoreception and other sense organs on the antennal flagellum of the grasshopper (Orthoptera: Acrididae). J Morphol 105, 145-151

Sturchow S, Holbert PE, Anstead JR (1973) Fine structure of the tip of labellar taste hair of the blow flies Phorma regina $(\mathrm{mg})$ and $\mathrm{Cal}$ - 
liphora vicina RD (Diptera: Callisphoridae). $Z$ Morphol Tiere 75, 87-109

Vogel R (1921) Zur Kenntnis der Geruchsorgane der Wespen und Biene. Zool Anz 53, 20-28

Wigglesworth VB (1965) The Principles of insect Physiology. Methuen Co Ltd, London, 6th edn
Yokohari $F$ (1978) Hygroreceptor mechanism in the antenna of the cockroach Periplaneta. $J$ Comp Physiol 124, 53-60

Yokohari F, Taneda H (1976) Moist and dry hygroreceptors for relative humidity of the cockroach, Periplaneta americana L. J Comp Physiol 106, 137-152 